\title{
Epigallocatechin-3-gallate inhibits inflammation and epithelial-mesenchymal transition through the PI3K/AKT pathway via upregulation of PTEN in asthma
}

\author{
NAN YANG, HAN ZHANG, XUXU CAI and YUNXIAO SHANG \\ Department of Pediatrics, Shengjing Hospital of China Medical University, Shenyang, Liaoning 110004, P.R. China
}

Received October 11, 2016; Accepted October 25, 2017

DOI: $10.3892 /$ ijmm.2017.3292

\begin{abstract}
Asthma is a chronic disease associated with hyperresponsiveness, obstruction and remodeling of the airways. Epithelial-mesenchymal transition (EMT) has an important role in these alterations and may account for the accumulation of subepithelial mesenchymal cells, thus contributing to airway hyperresponsiveness and remodeling. Epigallocatechin-3-gallate (EGCG), which is a type of polyphenol, is the most potent ingredient in green tea, and exhibits antibacterial, antiviral, antioxidative, anticancer and chemopreventive activities. Recently, numerous studies have investigated the protective effects of EGCG against asthma and other lung diseases. In the present study, the role of EGCG in ovalbumin (OVA)-challenged asthmatic mice was determined. In addition, the inhibitory effects of EGCG against transforming growth factor (TGF)- $\beta 1$-induced EMT and migration of $16 \mathrm{HBE}$ cells, and the underlying mechanisms of the phosphatidylinositol 3-kinase/protein kinase B (PI3K/AKT) signaling pathway, were investigated by immunofluorescence, Transwell, wound healing assay and western blot analysis, respectively. The results indicated that EGCG may suppress inflammation and inflammatory cell infiltration into the lungs of OVA-challenged asthmatic mice, and may also inhibit EMT via the PI3K/AKT signaling pathway through upregulating the expression of phosphatase and tensin homolog (PTEN) in vivo and in vitro. The present study also revealed the anti-migratory effects of EGCG in TGF- $\beta 1$-induced $16 \mathrm{HBE}$ cells, thus suggesting it may reduce airway remodeling. The present study provides a novel insight into understanding the protective effects of EGCG on airway remodeling in asthma, and indicates that EGCG may be useful as an adjuvant therapy for bronchial asthma.
\end{abstract}

Correspondence to: Dr Yunxiao Shang, Department of Pediatrics, Shengjing Hospital of China Medical University, 36 Sanhao Street, Shenyang, Liaoning 110004, P.R. China

E-mail: shangyunxiao827@163.com

Key words: phosphatase and tensin homolog, bronchial asthma, epigallocatechin-3-gallate, ovalbumin, epithelial-mesenchymal transition, phosphatidylinositol 3-kinase/protein kinase B

\section{Introduction}

Bronchial asthma is a complex syndrome that presents numerous clinical phenotypes in adults and children (1). Worldwide, 334 million people suffer from asthma, which is also one of the most common chronic disorders and an increasing burden on healthcare services globally (2). One of the major physiological alterations associated with asthma is narrowing of the airways due to exposure to bronchoconstrictors or allergens, which leads to hyperresponsiveness, obstruction and remodeling of the airways. Furthermore, structural alterations are associated with airway remodeling, including goblet cell hyperplasia or metaplasia, epithelial cell shedding, subepithelial fibrosis, smooth muscle cell hyperplasia, angiogenesis and edema (3). Epithelial-mesenchymal transition (EMT) has a key role in airway remodeling, which may account for the accumulation of subepithelial mesenchymal cells, thus contributing to airway hyperresponsiveness and the increasing mass of contractile cells (4). During the process of EMT, epithelial cells exhibit enhanced motility and invasive capacity via the downregulation of epithelial markers, including E-cadherin, and the increased expression of mesenchymal proteins $(5,6)$. EMT can be induced by growth factors, including transforming growth factor (TGF)- $\beta$, which is secreted from numerous cell types, such as infiltrating immune cells and airway epithelial cells $(7,8)$. Although current therapies, which include long-acting $\beta_{2}$ agonists, corticosteroids and leukotriene antagonists, remain effective in reducing inflammation, the majority of them are ineffective at preventing or suppressing airway remodeling (9). Therefore, agents that improve airway structure and reverse airway remodeling are required.

Epigallocatechin-3-gallate (EGCG), which is a type of polyphenol, is the most potent ingredient in green tea, and exhibits antibacterial, antiviral, antioxidative, anticancer and chemopreventive activities $(10,11)$. Notably, EGCG has recently been reported to contribute to the prevention of various degenerative diseases, including cardiovascular diseases, arthritis and diabetes $(12,13)$. Specifically, the number of studies investigating the protective effects of EGCG against asthma and lung diseases has risen dramatically (14-16). EGCG has been reported to inhibit nicotine-induced migration and invasion via the suppression of angiogenesis and EMT in non-small cell lung cancer cells (17). However, the exact cellular mechanism underlying the protective effects of EGCG against asthma has yet to be revealed. 
In the present study, ovalbumin (OVA)-challenged asthmatic mice and TGF- $\beta 1$-induced 16HBE human bronchial epithelial cells were used as in vivo and in vitro models, respectively. The protective effects of EGCG against TGF- $\beta 1$-induced EMT and migration of $16 \mathrm{HBE}$ cells, and the underlying mechanisms associated with phosphatidylinositol 3-kinase/protein kinase B (PI3K/AKT) signaling pathway regulation, were investigated. The present study provides a novel insight into understanding the protective effects of EGCG against airway remodeling in asthma, and proposes that EGCG may be useful as an adjuvant therapy for bronchial asthma.

\section{Materials and methods}

Ethics statement. Male Balb/c mice (6 mice each group, age, 6-8 weeks; weight, 20-22 g) were used in the present study. Mice were procured from Beijing Vital River Laboratory Animal Technology Co., Ltd. (Beijing, China) and were acclimated for 1 week under standard laboratory conditions. Mice were acclimatized for a week under standard laboratory conditions and provided with standard irradiated chow diet ad libitum and maintained in a specific pathogen-free state under a strict light cycle $(12: 12 \mathrm{~h})$ at a temperature of $22 \pm 2^{\circ} \mathrm{C}$ and a relative humidity of $50 \pm 10 \%$. All animal experiments were performed according to the Institutional Animal Care and Use Committees and were approved by the China Medical University Animal Care and Use Committee (Shenyang, China).

OVA-induced asthma model. Mice were sensitized with $10 \mu \mathrm{g}$ OVA (Sigma-Aldrich; Merck KGaA, Darmstadt, Germany) mixed with $2 \mathrm{mg}$ aluminum hydroxide in saline by intraperitoneal (i.p.) injection once a week for 3 weeks. After 2 weeks, the mice were challenged with aerosolized $1 \%$ OVA for $30 \mathrm{~min}$ three times a week for 8 weeks, and were euthanized $24 \mathrm{~h}$ after the last challenge. The non-sensitized mice were nebulized by saline in the same manner. All mice were sacrificed at day 56 ( $24 \mathrm{~h}$ after the last OVA treatment). The lungs were lavaged with $0.8 \mathrm{ml}$ cold PBS and bronchoalveolar lavage fluid (BALF) was processed for differential cell counting, and determination of cytokines and chemokines. For another set of experiments, the lung tissues were fixed with $4 \%$ paraformaldehyde (Sinopharm Chemical Reagent Co., Ltd., Shanghai, China) and histological examination was performed with hematoxylin and eosin (H\&E) staining.

BALF differential cell count. BALF samples were initially centrifuged at $800 \mathrm{x}$ g for $10 \mathrm{~min}$ and supernatants were frozen at $-70^{\circ} \mathrm{C}$ for assessment of inflammatory chemokines/ cytokines. The total number of cells was counted using a cell counter and was recorded as the total number of inflammatory cells per ml. The cell suspension was harvested for cytokine analysis and the pellet was smeared onto slides for cell classification and counting. The cell smear was stained with Wright-Giemsa (Nanjing Jiangcheng Bioengineering Institute, Nanjing, China), after which the number of leukocytes, eosinophils, macrophages and neutrophils were recorded by counting under a light microscopy.

Treatment with EGCG. EGCG $(0.5 \mathrm{mg} / \mathrm{ml}$; Sigma-Aldrich; Merck KGaA) was administered in drinking water, which was provided ad libitum $1 \mathrm{~h}$ after the first OVA challenge until the mice were sacrificed. Dexamethasone (DEX, $1 \mathrm{mg} / \mathrm{kg}$; Dalian Meilun Biotech Co., Ltd., Dalian, China), which was used as a positive control, was injected (i.p.) $1 \mathrm{~h}$ prior to every nebulization.

Cell culture. The 16HBE human bronchial epithelial cell line (FMGBio Co., Ltd., Shanghai, China) was cultured in Dulbecco's modified Eagle's medium containing $100 \mathrm{U}$ penicillin, $100 \mathrm{mg} / \mathrm{ml}$ streptomycin (all Gibco; Thermo Fisher Scientific, Inc., Waltham, MA, USA) and 10\% fetal bovine serum (FBS; Hyclone; GE Healthcare Life Sciences, Logan, UT, USA) in a humidified incubator containing $5 \% \mathrm{CO}_{2}$ at $37^{\circ} \mathrm{C}$. Cells were initially pretreated with $5 \mathrm{ng} / \mathrm{ml}$ TGF- $\beta 1$ (PeproTech, Inc., Rocky Hill, NJ, USA) at $37^{\circ} \mathrm{C}$ for $24 \mathrm{~h}$ and were then cotreated with $50 \mu \mathrm{M}$ EGCG (Sigma-Aldrich; Merck $\mathrm{KGaA}$ ) at $37^{\circ} \mathrm{C}$ for a further $24 \mathrm{~h}$. In order to investigate the effects of the PI3K pathway, cells were pretreated with LY294002 (Sigma-Aldrich; Merck KGaA) at $37^{\circ} \mathrm{C}$ for $1 \mathrm{~h}$ prior to treatment with TGF- $\beta$.

ELISA. Samples from mice treated with or without OVA and/or EGCG were harvested and washed twice in cold PBS. The concentrations of interleukin (IL)-4, IL-5 and TGF- $\beta 1$ in the BALF or whole lung tissues were determined using mouse IL-4/-5 and mouse TGF- $\beta 1$ detection kits (EK0405, EK0408 and EK0515; Wuhan Boster Biological Technology, Ltd., Wuhan, China) according to the manufacturer's protocols. Protein concentrations were determined using a bicinchoninic acid (BCA) protein assay kit (Beyotime Institute of Biotechnology, Shanghai, China) according to the manufacturer's protocol. All of the samples, and the standards diluted to different concentrations, were added to the wells at a volume of $100 \mu \mathrm{l}$. The absorbance was measured using a microplate reader (BioTek Instruments, Inc., Winooski, VT, USA) at $450 \mathrm{~nm}$, and the concentration levels of IL-4, IL-5 and TGF- $\beta 1$ were calculated from the standard curve.

Western blot analysis. Proteins were harvested from the lung tissues of asthmatic mice treated with or without EGCG, and from cells pretreated with $5 \mathrm{ng} / \mathrm{ml}$ TGF- $\beta 1$ for $24 \mathrm{~h}$ and then coincubated with $50 \mu \mathrm{M}$ EGCG for a further $24 \mathrm{~h}$. Tissue or cell extracts were prepared in ice-cold radioimmunoprecipitation buffer plus phenylmethylsulfonyl fluoride (both Beyotime Institute of Biotechnology) for $30 \mathrm{~min}$ on ice. The lysates were centrifuged at $20,000 \mathrm{x} \mathrm{g}$ for $10 \mathrm{~min}$ at $4^{\circ} \mathrm{C}$. Subsequently, protein concentration was determined using a BCA protein assay kit according to the manufacturer's protocol. Total proteins $(40 \mu \mathrm{g})$ were separated by $5-10 \%$ SDS-PAGE for $2.5 \mathrm{~h}$, after which the separated proteins were transferred to polyvinylidene difluoride membranes (EMD Millipore, Billerica, MA, USA) for $1.5 \mathrm{~h}$ at $80 \mathrm{~V}$. After that, the PVDF membranes were blocked with TTBS buffer sharking for $5 \mathrm{~min}$, then the membranes were transferred into blocking buffer (95\% TTBS buffer and 5\% skimmed milk powder) sharking for $1 \mathrm{~h}$ at room temperature. Each membrane was then incubated with the following primary antibodies: Anti-phosphorylated (p)-AKT (cat. no. sc-135651) and anti-AKT (cat. no. sc-8312) (1:200; both Santa Cruz Biotechnology, Inc., Dallas, TX, USA); anti-phosphatase and tensin homolog (PTEN; cat. no. ab32199, 1:1,000; Abcam, Cambridge, MA, USA); anti-PI3K (cat. no. BA1352, 
1:400; Wuhan Boster Biological Technology, Ltd.); anti-p-PI3K (cat. no. bs-5538R, 1:500; BIOSS, Beijing, China); anti-E-cadherin (cat. no. WL00941), anti- $\alpha$-smooth muscle actin ( $\alpha$-SMA; cat. no. WL0002a) and anti- $\beta$-actin (cat. no. WL0001) $(1: 1,000$; Wanleibio Co., Ltd., Shenyang, China) overnight at $4^{\circ} \mathrm{C}$. Subsequently, the membranes were washed with TBST buffer (150 mM NaCl, $10 \mathrm{mM}$ Tris- $\mathrm{HCl}$ and 1\% Tween-20) for $30 \mathrm{~min}$ and were incubated with horseradish peroxidase-conjugated goat anti-rabbit immunoglobulin G (cat. no. A0208, 1:5,000; Beyotime Institute of Biotechnology) at room temperature for $1 \mathrm{~h}$. Finally, the blots were developed using an enhanced chemiluminescence detection (ECL) kit (ECL detection reagent; 7Sea Biotech, Shanghai, China). $\beta$-actin was used as an internal positive control. The relative amounts of the transferred proteins were semi-quantified by scanning the autoradiographic films using a gel densitometer and normalizing the levels to those of $\beta$-actin. Semi-quantitative analysis was conducted using Gel-Pro Analyzer software (version 4.0; Media Cybernetics, Inc., Rockville, MD, USA).

Reverse transcription-quantitative polymerase chain reaction $(R T-q P C R)$. RNA was extracted from cells pretreated with $5 \mathrm{ng} / \mathrm{ml}$ TGF- $\beta 1$ for $24 \mathrm{~h}$ then coincubated with $50 \mu \mathrm{M}$ EGCG for a further 24 h. Total RNA was extracted using a high purity total RNA extraction kit (BioTeke Corporation, Beijing, China) according to the manufacturer's protocol. mRNA expression levels were then examined by RT-qPCR using total RNA. cDNA was synthesized from total RNA using the Super M-MLV RT kit at $25^{\circ} \mathrm{C}$ for $10 \mathrm{~min}$, at $42^{\circ} \mathrm{C}$ for $50 \mathrm{~min}$, at $95^{\circ} \mathrm{C}$ for $5 \mathrm{~min}$ (BioTeke Corporation). cDNA was then amplified by qPCR. Primers used for RT-qPCR were as follows: E-cadherin forward, 5'-ATGCCGCCATCGCTTACAC-3' and reverse, 5'-CGACGTTAGCCTCGTTCTCA-3'; $\alpha$-SMA forward, 5'-CCTGAAGAGCATCCCACCCT-3' and reverse, 5'-ACCATCTCCAGAGTCCAGCACG-3'; PTEN forward, 5'-AAGGAAGTGAATCTGTATTGGGGT-3' and reverse, 5'-TTGTTGCTGTGTTTCTTACCTATG-3'; and $\beta$-actin forward, 5'-CTTAGTTGCGTTACACCCTTTCTTG-3' and reverse, 5'-CTGTCACCTTCACCGTTCCAGTTT-3'. Each RT-qPCR experiment consisted of a predenaturation cycle at $95^{\circ} \mathrm{C}$ for $10 \mathrm{~min}$; subsequently, the cDNA was amplified for 40 cycles, including a denaturation step at $95^{\circ} \mathrm{C}$ for $10 \mathrm{sec}$, a primer annealing step at $60^{\circ} \mathrm{C}$ for $20 \mathrm{sec}$ and an extension step at $72^{\circ} \mathrm{C}$ for $30 \mathrm{sec}$; finally, the samples were maintained at $4^{\circ} \mathrm{C}$ for $5 \mathrm{~min}$. The PCR results were verified by varying the number of PCR cycles for each cDNA and set of primers. qPCR was performed using an Exicycler ${ }^{\mathrm{TM}} 96$ Real-Time Quantitative Thermal block (Bioneer Corporation, Daejeon, Korea) with $\beta$-actin as a control. RT-qPCR was performed at least in quadruplicate. The $2^{-\Delta \Delta \mathrm{Ct}}$ method was used to determine the relative mRNA folding changes (18). Data are presented as the mean of the results from at least three experiments.

Transwell assay. Transwell chambers (Corning Inc., Corning, NY, USA) were used to measure cell migration. Cells that were pretreated with $5 \mathrm{ng} / \mathrm{ml}$ TGF- $\beta 1$ for $24 \mathrm{~h}$ or LY294002 for $1 \mathrm{~h}$, then coincubated with $50 \mu \mathrm{M}$ EGCG for a further $24 \mathrm{~h}$, were seeded into the upper chamber at a density of $2 \times 10^{4}$ in $200 \mu \mathrm{l}$ fresh medium without FBS. In the lower chamber, $800 \mu 1$ medium supplemented with $20 \%$ FBS was added. Three duplicate wells were set up for each group. Following $24 \mathrm{~h}$ incubation at $37^{\circ} \mathrm{C}$, cells infiltrating through the filter were fixed with $4 \%$ paraformaldehyde for $20 \mathrm{~min}$ and were stained with $0.5 \%$ crystal violet (Amresco, LLC, Solon, OH, USA) for $5 \mathrm{~min}$. Cell numbers on the lower membrane were counted under high power lens (x200 magnification) in five random visual fields using an inverted microscope (Motic Incorporation, Ltd., Hong Kong, China).

Wound healing assay. Cells were seeded onto 6-well plates until they reached $80-90 \%$ confluence. Subsequently, the cells were pretreated with $5 \mathrm{ng} / \mathrm{ml} \mathrm{TGF}-\beta 1$ for $24 \mathrm{~h}$ or LY294002 for $1 \mathrm{~h}$, and were then coincubated with $50 \mu \mathrm{M}$ EGCG for a further $24 \mathrm{~h}$. The medium was then discarded and a straight scratch was made to the cell layer using a $200-\mu 1$ pipette tip, to simulate a wound. The plates were washed with serum-free medium, and the cells were observed and images were captured under a inverted phase contrast microscope (AE31; Motic Incorporation, Ltd.) to ensure there were enough cells in the leading edge of the wound. Cell culture continued in serum-free medium at $37^{\circ} \mathrm{C}$ for 12 and $24 \mathrm{~h}$, after which images were captured. The rate of migration of the cells was calculated by measuring the distance traveled toward the center of the wound.

Histological analysis. The lung tissues collected from asthmatic mice treated with or without EGCG were fixed with $4 \%$ paraformaldehyde for $30 \mathrm{~min}$, embedded in paraffin wax and then sectioned at room temperature into 5- $\mu \mathrm{m}$ slices. The sections were stained with hematoxylin (Beijing Solarbio Science \& Technology Co., Ltd., Beijing, China) and eosin (Sinopharm Chemical Reagent Co., Ltd.). Morphological features of the sections were observed under a light microscope (DP73; Olympus Corporation, Tokyo, Japan).

Immunofluorescence. Immunofluorescent staining was performed on paraffin-embedded lung tissue sections obtained from asthmatic mice. Samples from lung tissues were isolated, fixed with $4 \%$ paraformaldehyde at room temperature for $20 \mathrm{~min}$ and embedded in paraffin wax. Microwave antigen retrieval was conducted in citrate buffer for $10 \mathrm{~min}$, followed by $15 \mathrm{~min}$ of cooling at room temperature. Slides and tissue sections were blocked and permeabilized in $2 \%$ goat serum (OriGene Technologies, Inc., Beijing, China) at room temperature for $30 \mathrm{~min}$, and were then incubated with anti-E-cadherin (cat. no. sc-8426, 1:50; Santa Cruz Biotechnology, Inc.) and anti- $\alpha$-SMA (cat. no. 14395-1-AP, 1:200; ProteinTech Group, Inc., Chicago, IL, USA) antibodies at $4^{\circ} \mathrm{C}$ overnight. Sections were then incubated with a secondary antibody [FITC-labeled goat anti-mouse IgG $(\mathrm{H}+\mathrm{L})$, cat. no. A0568; and Cy3-labeled goat anti-rabbit $\operatorname{IgG}(\mathrm{H}+\mathrm{L})$, cat. no. A0516; Beyotime Institute of Biotechnology] in blocking reagent at room temperature for $90 \mathrm{~min}$. Both antibodies were diluted in $1 \%$ bull serum albumin in PBS. Samples were counterstained with DAPI (Beyotime Institute of Biotechnology) and observed under an inverted fluorescence microscope (Olympus Corporation); all images were taken at x400 magnification. Semi-quantitative analysis of immunofluorescent staining was conducted using Image-Pro Plus 6.0 (Media Cybernetics, Inc.) software and the results are presented as average optical density (AOD) values.

Statistical analysis. All data are expressed as the mean \pm standard deviation from at least three experiments. Data were 
A
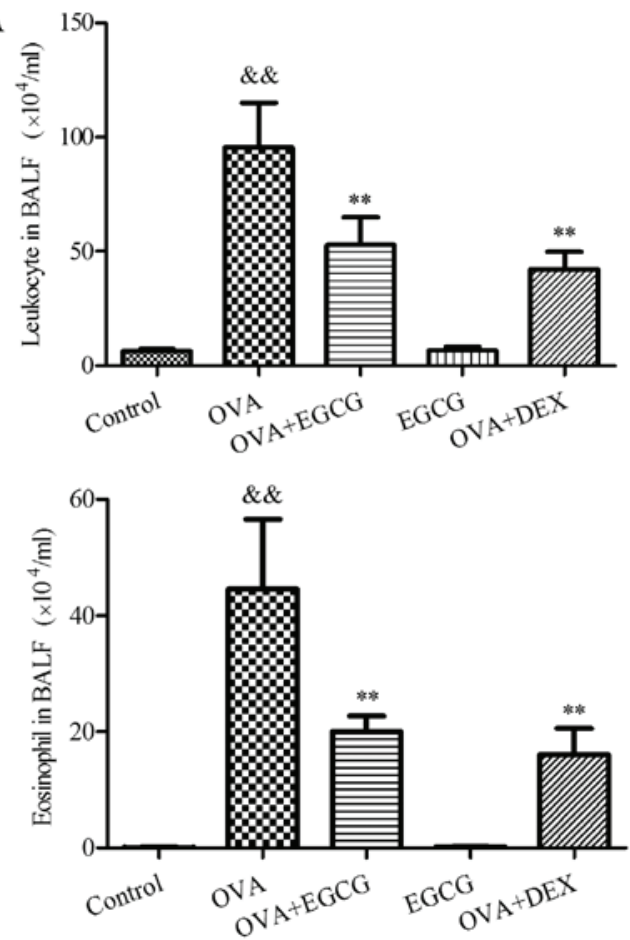

B

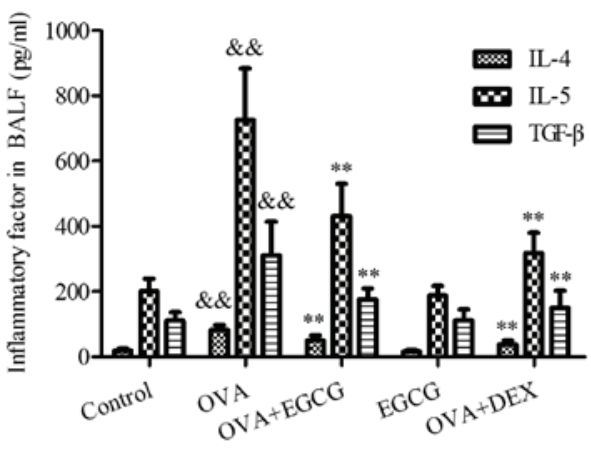

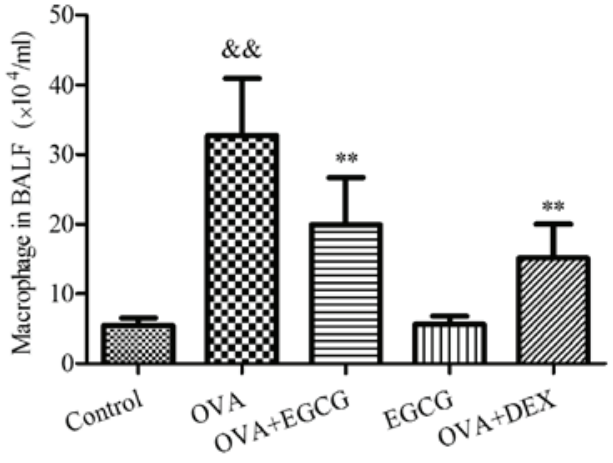

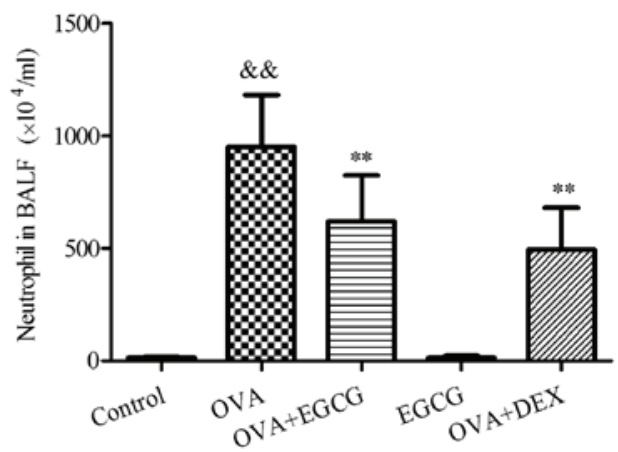

$\mathrm{C}$

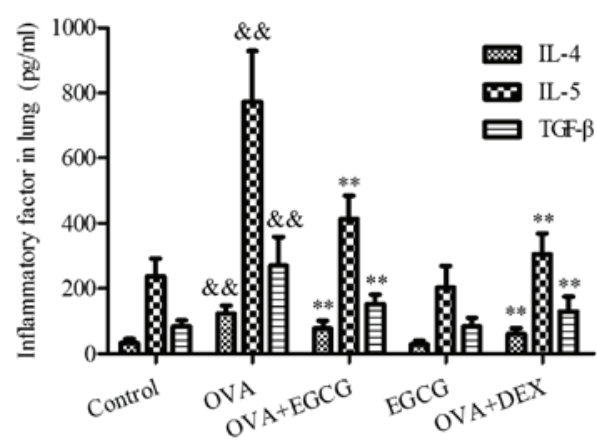

D
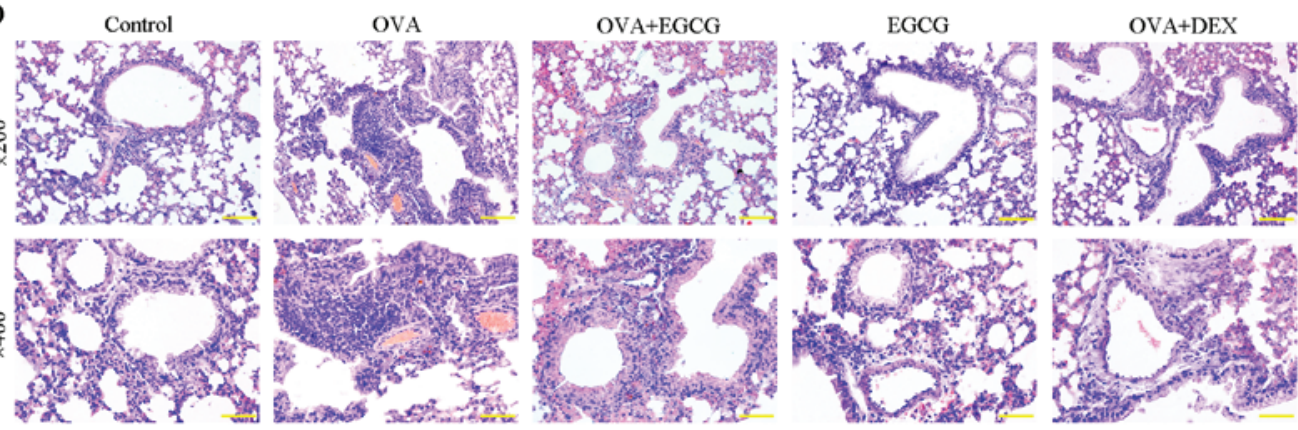

Figure 1. EGCG inhibits lung inflammation and inflammatory cell infiltration into the lungs of OVA-challenged asthmatic mice. (A) EGCG inhibited leukocyte accumulation in the BALF of OVA-challenged asthmatic mice. The total, as well as differential, cell counts were measured in the BALF collected following the final OVA challenge. The number of total cells, macrophages, eosinophils and neutrophils per ml of BALF is presented as the mean \pm standard deviation ( $n=6$ ). EGCG inhibited the expression of IL-4, IL-5 and TGF- $\beta$ in (B) BALF and (C) lung tissues following an OVA challenge. IL-4, IL-5 and TGF- $\beta$ levels were measured by ELISA. (D) H\&E staining. Fixed lungs from the different experimental groups were sectioned, stained with H\&E and examined under a light microscope. A representative image from each group is shown ( $\mathrm{n}=6$, $\mathrm{x} 200$ and $\mathrm{x} 400 \mathrm{magnification}$ ). DEX was used as a positive control. Data are are presented as the mean \pm standard deviation. ${ }^{\&} \mathrm{P}<0.01$ vs. the control group; ${ }^{* *} \mathrm{P}<0.01$ vs. the OVA group. BALF, bronchoalveolar lavage fluid; DEX, dexamethasone; EGCG, epigallocatechin-3-gallate; H\&E, hematoxylin and eosin; IL, interleukin; OVA, ovalbumin; TGF- $\beta$, transforming growth factor- $\beta$.

analyzed using the one-way analysis of variance followed by Bonferroni's multiple comparisons, where appropriate. $\mathrm{P}<0.05$ was considered to indicate a statistically significant difference. Statistical analyses were performed using Prism version 5.0 (GraphPad Software, Inc., La Jolla, CA, USA).

\section{Results}

EGCG inhibits inflammation and inflammatory cell infiltration into the lungs of OVA-challenged asthmatic mice. During the pathological process of chronic asthma, antigen-induced 

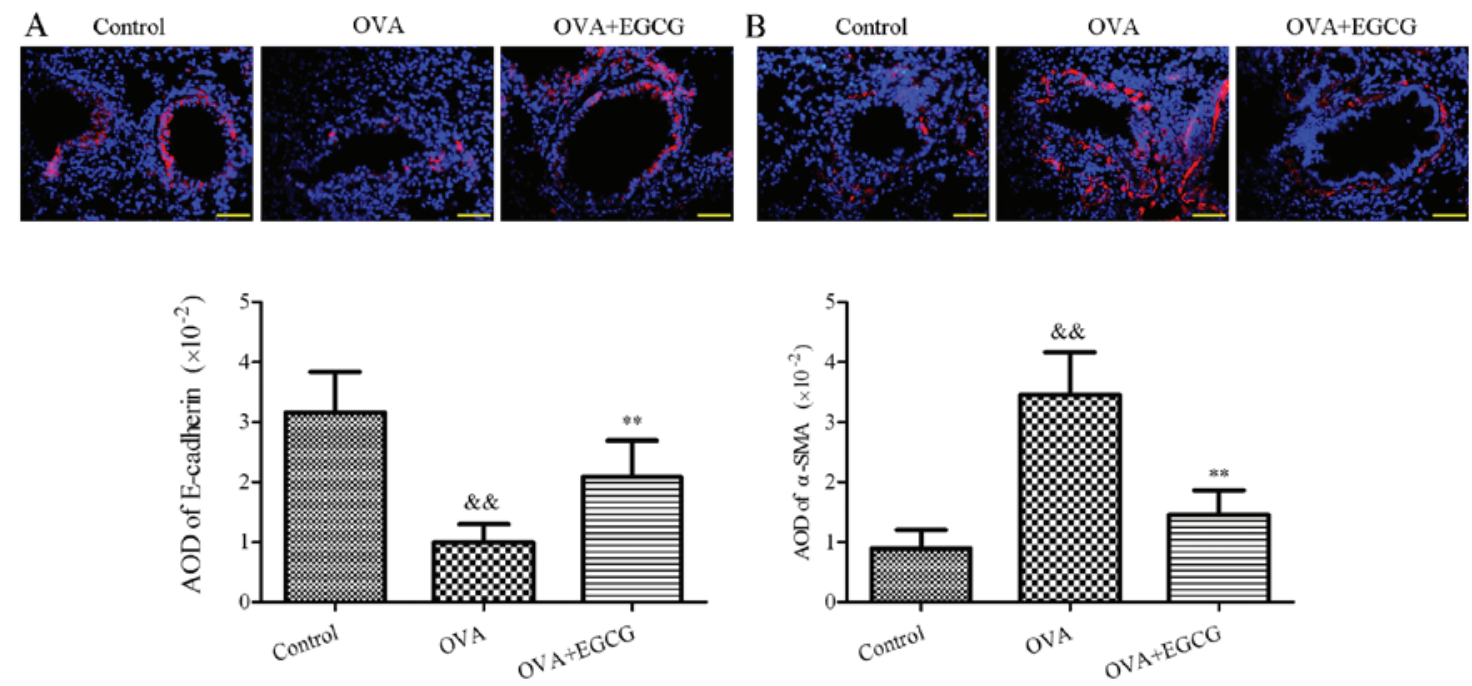

Figure 2. EGCG suppresses airway epithelial-mesenchymal transition in OVA-challenged asthmatic mice. (A) EGCG increased the expression levels of E-cadherin in the airways of asthmatic mice. The expression levels of E-cadherin were detected using immunofluorescence analysis and the AOD values of E-cadherin were calculated. Magnification, x400. (B) EGCG decreased the expression levels of $\alpha$-SMA in the airways of asthmatic mice, as determined by immunofluorescence analysis. Data are presented as the mean \pm standard deviation. ${ }^{\& \&} \mathrm{P}<0.01$ vs. the control group; **P $<0.01$ vs. the OVA group. $\alpha$-SMA, $\alpha$-smooth muscle actin; AOD, average optical density; EGCG, epigallocatechin-3-gallate; OVA, ovalbumin.

airway inflammation is characterized by an increased number of inflammatory cells into the lung subepithelial spaces or the airways (19). Therefore, the effects of EGCG on the accumulation of inflammatory cells in the BALF and their infiltration into the lungs were examined following an OVA challenge. As shown in Fig. 1A, there was a significant increase in the number of total leukocytes in the BALF from OVA-sensitized and challenged mice (from $6.25 \pm 1.08$ to $95.5 \pm 19.60 \times 10^{4} / \mathrm{ml}$, $\mathrm{P}<0.01)$. Conversely, the number of total leukocytes was significantly decreased in the BALF of OVA-challenged mice treated with EGCG (from $95.5 \pm 19.60$ to $52.8 \pm 12.1 \times 10^{4} / \mathrm{ml}, \mathrm{P}<0.01$ ) Furthermore, the number of macrophages was significantly decreased (from $32.7 \pm 8.20 \times 10^{4} / \mathrm{ml}$ in the OVA group to $19.91 \pm 6.79 \times 10^{4} / \mathrm{ml}$ in the OVA + EGCG group, $\left.\mathrm{P}<0.01\right)$, whereas the number of eosinophils (from $44.58 \pm 12.04 \times 10^{4} / \mathrm{ml}$ in the OVA group to $20.0 \pm 2.70 \times 10^{4} / \mathrm{ml}$ in the $\mathrm{OVA}+\mathrm{EGCG}$ group, $\left.\mathrm{P}<0.01\right)$ and neutrophils (from $951.44 \pm 231.26 \times 10^{4} / \mathrm{ml}$ in the OVA group to $620.67 \pm 205.3610^{4} / \mathrm{ml}$ in the OVA + EGCG group, $\mathrm{P}<0.01$ ) were decreased by $40-50 \%$ in the BALF of EGCG-treated OVA-challenged mice compared with in OVA-challenged mice. In addition, the effects of EGCG on asthmatic mice were comparable to those of the standard drug DEX.

Protein levels of IL-4, IL-5 and TGF- $\beta 1$ were detected in the BALF (Fig. 1B) and lung tissues (Fig. 1C) of mice following an OVA challenge using ELISA. As shown in Fig. 1B, OVA induced a significant increase in these cytokines in the BALF compared with in the control group. The concentrations of IL-4, IL- 5 and TGF- $\beta 1$ in the control group vs. the OVA group were: $33.32 \pm 12.72$ vs. $122.94 \pm 25.22 \mathrm{pg} / \mathrm{ml}, 237.80 \pm 54.10$ vs. $772.11 \pm 156.86 \mathrm{pg} / \mathrm{ml}$ and $83.41 \pm 19.36$ vs. $270.24 \pm 88.77 \mathrm{pg} / \mathrm{ml}$, respectively $(\mathrm{P}<0.01$, Fig. 1B). Administration of EGCG during OVA challenge normalized the elevated cytokine levels, with potent effects on IL-4, IL-5 and TGF- $\beta 1$ in the OVA + EGCG group. The concentrations of the cytokines were as follows: IL-4, $122.94 \pm 25.22 \mathrm{pg} / \mathrm{ml}$ in the OVA group vs. $77.02 \pm 24.95 \mathrm{pg} / \mathrm{ml}$ in the OVA + EGCG group; IL-5, 772.11 $\pm 156.86 \mathrm{pg} / \mathrm{ml}$ in the
OVA group vs. $413.11 \pm 73.11 \mathrm{pg} / \mathrm{ml}$ in the OVA + EGCG group; and TGF- $\beta 1,270.24 \pm 88.77 \mathrm{pg} / \mathrm{ml}$ in the OVA group vs. $152.92 \pm 29.23 \mathrm{pg} / \mathrm{ml}$ in the OVA + EGCG group $(\mathrm{P}<0.01$; Fig. 1B). In addition, the levels of IL-4, IL-5 and TGF- $\beta 1$ in the lung tissues from OVA-challenged mice exhibited similar trends to those in the BALF. The results demonstrated that OVA increased the IL-4 levels from $18.88 \pm 5.33 \mathrm{pg} / \mathrm{ml}$ in the control group to $82.02 \pm 15.70 \mathrm{pg} / \mathrm{ml}$ in the OVA group. In addition, IL-5 levels were increased from $201.37 \pm 37.18 \mathrm{pg} / \mathrm{ml}$ in the control group to $726.11 \pm 157.35 \mathrm{pg} / \mathrm{ml}$ in the OVA group, whereas TGF- $\beta 1$ were increased from $110.86 \pm 25.70 \mathrm{pg} / \mathrm{ml}$ in the control group vs. $311.44 \pm 102.33 \mathrm{pg} / \mathrm{ml}$ in the OVA group $(\mathrm{P}<0.01$, Fig. $1 \mathrm{C})$. However, administration of EGCG inhibited these increased cytokine levels (IL-4, from $82.02 \pm 15.70$ to $49.85 \pm 15.92 \mathrm{pg} / \mathrm{ml}$; IL-5, from $726.11 \pm 157.35$ to $431.13 \pm 99.40 \mathrm{pg} / \mathrm{ml}$; and TGF- $\beta 1$ from $311.44 \pm 102.33$ to $176.25 \pm 33.67 \mathrm{pg} / \mathrm{ml}, \mathrm{P}<0.01$, Fig. 1C), whereas administration of EGCG alone (EGCG group) had no effect on cytokine response in the BALF and lung tissues compared with in the control group. In addition, the effects of EGCG were compared with those of DEX; no significant differences were detected between the two groups.

$\mathrm{H} \& \mathrm{E}$ staining revealed that inflammatory cell infiltration, particularly of eosinophils (red staining) as well as other inflammatory cells (blue staining), into the peribronchial and perivascular spaces of OVA-challenged mice was increased (Fig. 1D). Conversely, in EGCG-treated asthmatic mice, infiltration of eosinophils and other inflammatory cells into the lung tissue was markedly decreased compared with in OVA-challenged mice (Fig. 1D). These results indicated that EGCG inhibits lung inflammation in OVA-challenged asthmatic mice with the same effect as DEX, which is an anti-inflammatory and anti-immune disease drug.

EGCG suppresses airway EMT in OVA-challenged asthmatic mice. The present study demonstrated that the expression levels of TGF- $\beta 1$ were markedly enhanced in OVA-challenged 
A
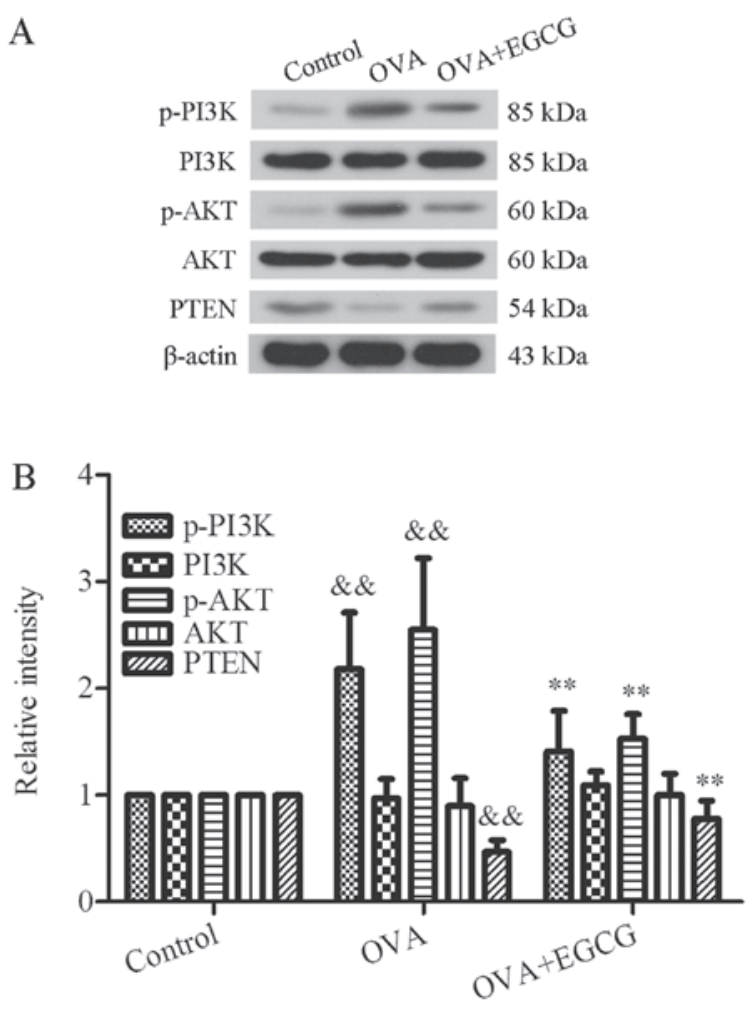

Figure 3. EGCG inhibits the PI3K/AKT signal pathway via the upregulation of PTEN in OVA-challenged chronic asthmatic mice. (A) EGCG downregulated the expression of p-PI3K and p-AKT, and upregulated PTEN expression in lung tissues of OVA-challenged asthmatic mice, as determined by western blot analysis. (B) Blots underwent semi-quantitative analysis of gray intensity. Data are presented as the mean \pm standard deviation. ${ }^{\&} \mathrm{P}<0.01$ vs. the control group; ${ }^{* *} \mathrm{P}<0.01$ vs. the OVA group. AKT, protein kinase $\mathrm{B}$; EGCG, epigallocatechin-3-gallate; OVA, ovalbumin; p-, phosphorylated; PI3K, phosphatidylinositol 3-kinase; PTEN, phosphatase and tensin homolog.

mice (Fig. 1); the increased levels of TGF- $\beta 1$ may initiate signaling cascades in epithelial cells that lead to EMT. To determine the effects of EGCG on OVA-challenged asthmatic mice, the expression levels of the epithelial marker E-cadherin and the mesenchymal marker $\alpha$-SMA were detected in the airways of asthmatic mice with or without EGCG treatment by immunofluorescence analysis. The results indicated that the airways of mice challenged with OVA exhibited reduced E-cadherin expression and increased $\alpha$-SMA expression compared with in the healthy control mice; however, EGCG increased the expression of E-cadherin and decreased the expression of $\alpha$-SMA (Fig. 2A and B). The AOD values of E-cadherin and $\alpha$-SMA were as follows: E-cadherin expression was reduced from $3.17 \pm 0.67\left(\times 10^{-2}\right)$ in the control group to $1.00 \pm 0.30\left(\times 10^{-2}\right)$ in the OVA group, and $\alpha$-SMA expression was increased from $0.90 \pm 0.30\left(\times 10^{-2}\right)$ in the control group to $3.46 \pm 0.71\left(\times 10^{-2}\right)$ in the OVA group $(\mathrm{P}<0.01)$. In the OVA + EGCG group, the AOD values of $E$-cadherin were increased from 1.00 \pm 0.30 to $2.09 \pm 0.60\left(\times 10^{-2}\right)$, whereas the AOD values of $\alpha$-SMA were decreased from $3.46 \pm 0.71$ to $1.46 \pm 0.40\left(\times 10^{-2}\right)$ (Fig. 2A and B). These results suggested that EGCG may attenuate EMT via increasing the levels of E-cadherin and suppressing $\alpha$-SMA expression in OVA-challenged asthmatic mice.

EGCG inhibits the PI3K/AKT signal pathway via upregulation of PTEN in OVA-challenged asthmatic mice. To

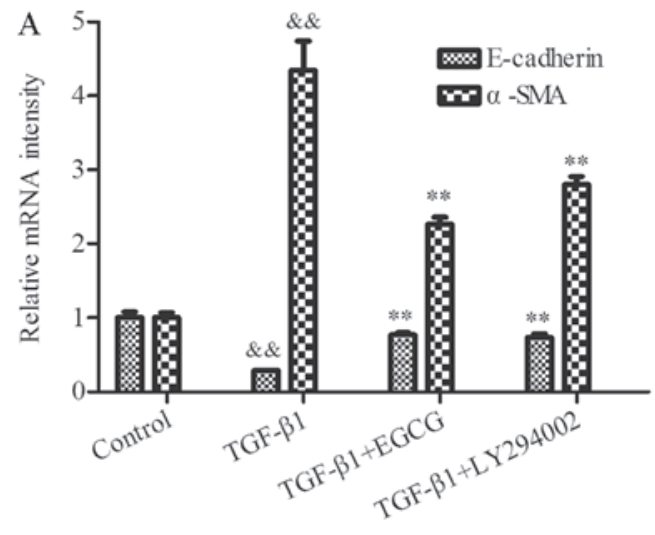

B
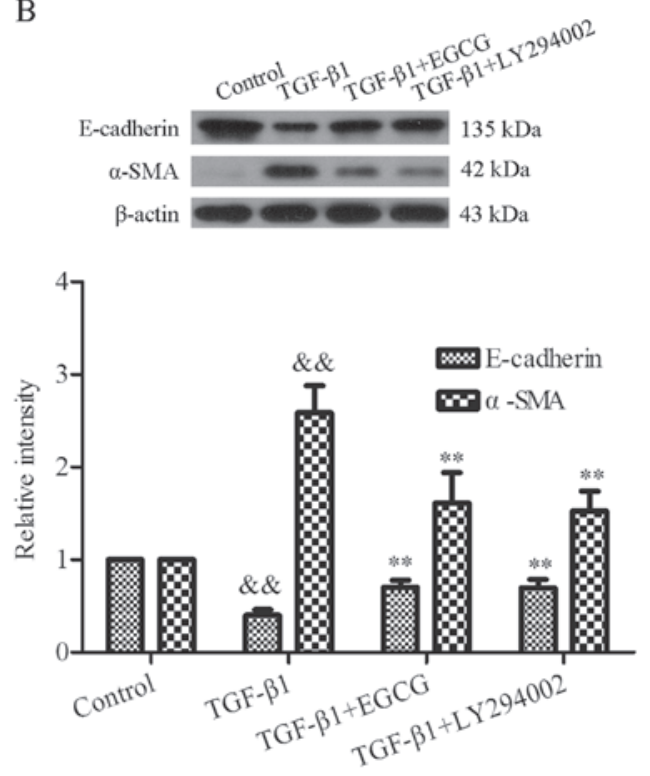

Figure 4. EGCG suppresses epithelial-mesenchymal transition in TGF- $\beta 1$-induced $16 \mathrm{HBE}$ cells. (A) Relative mRNA expression levels of E-cadherin and $\alpha$-SMA in TGF- $\beta 1$-induced $16 \mathrm{HBE}$ cells, as determined by reverse transcription-quantitative polymerase chain reaction analysis. (B) Protein expression levels of E-cadherin and $\alpha$-SMA in TGF- $\beta 1$-induced $16 \mathrm{HBE}$ cells, as determined by western blot analysis. Blots underwent semi-quantitative analysis of gray intensity. Data are presented as the mean \pm standard deviation. ${ }^{\& \&} \mathrm{P}<0.01$ vs. the control group; ${ }^{* *} \mathrm{P}<0.01$ vs. the TGF- $\beta 1$ group. $\alpha$-SMA, $\alpha$-smooth muscle actin; EGCG, epigallocatechin-3-gallate; LY294002, inhibitor of phosphatidylinositol 3-kinase activity; TGF- $\beta 1$, transforming growth factor- $\beta 1$.

determine the effects of EGCG on the PI3K/AKT signaling pathway, the expression levels of PI3K, p-PI3K, AKT and p-AKT were detected in OVA-challenged lung tissue with or without EGCG treatment by western blot analysis (Fig. 3). As shown in Fig. 3A, compared with in the control group, the expression levels of PI3K and AKT were not changed, whereas the expression levels of $\mathrm{p}$-PI3K and $\mathrm{p}$-AKT were upregulated in the OVA group. Conversely, the expression levels of p-PI3K and p-AKT were significantly reduced by EGCG treatment. Semi-quantitative analysis of p-PI3K and p-AKT expression indicated that $\mathrm{p}$-PI3K expression was decreased from $2.18 \pm 0.53$ in the OVA group to $1.41 \pm 0.38$ in the OVA + EGCG group, and p-AKT expression was decreased from $2.55 \pm 0.67$ in the OVA group to $1.53 \pm 0.23$ in the OVA + EGCG group $(\mathrm{P}<0.01$, Fig. 3B). Therefore, treatment with EGCG may decrease the phosphorylation of PI3K and AKT. Furthermore, 
A
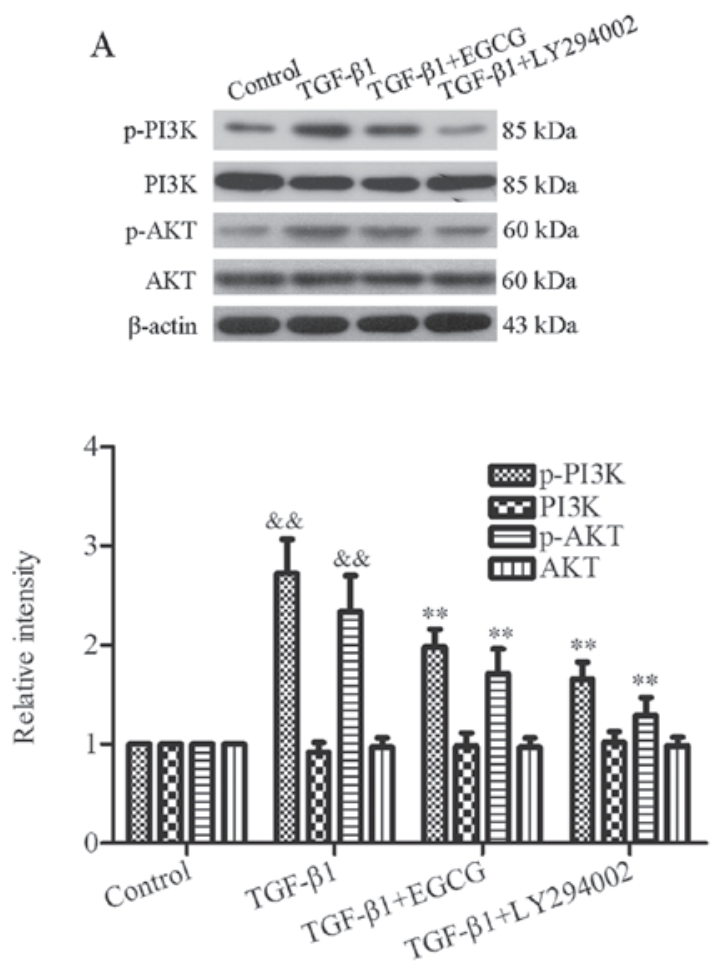
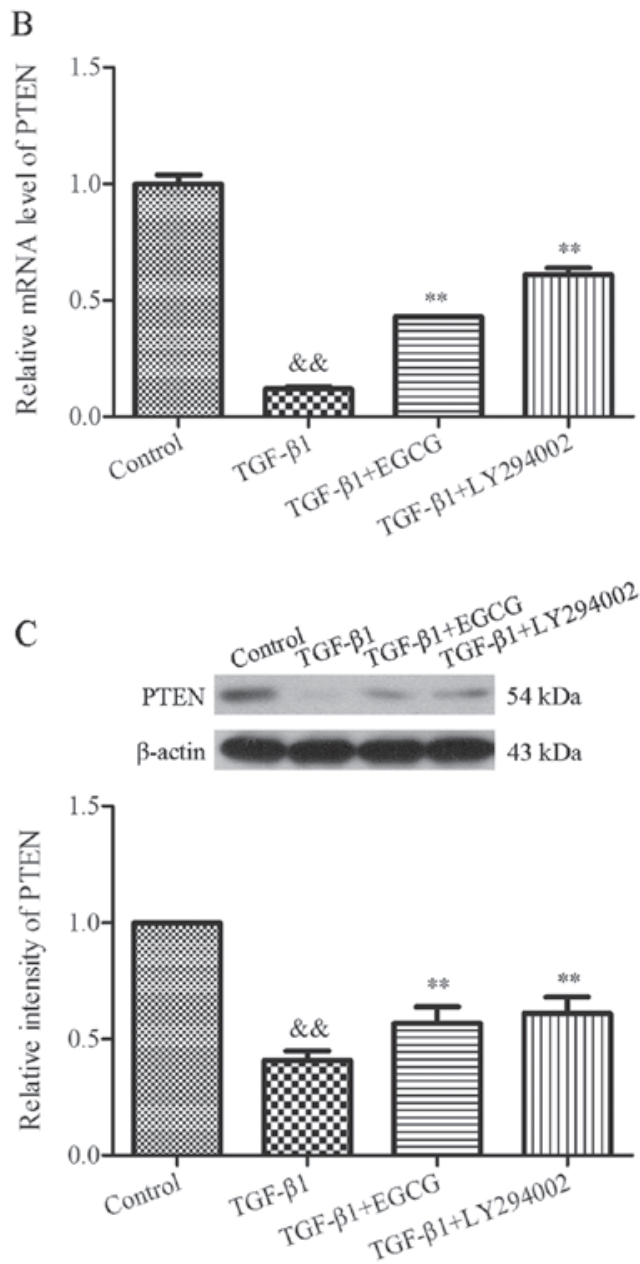

Figure 5. EGCG inhibits the PI3K/AKT signal pathway via upregulation of PTEN in TGF- $\beta 1$-induced 16HBE cells. (A) Protein expression levels of p-PI3K, PI3K, p-AKT and AKT following treatment of TGF- $\beta 1$-induced 16HBE cells with or without EGCG were determined by western blot analysis. Blots underwent semi-quantitative analysis of gray intensity. (B) Relative mRNA expression levels of PTEN in TGF- $\beta 1$-induced 16HBE cells, as determined by reverse transncription-quantitative polymerase chain reaction analysis. (C) Protein expression levels of PTEN following treatment of TGF- $\beta 1$-induced 16HBE cells with or without EGCG, as determined by western blot analysis. Blots underwent semi-quantitative analysis of gray intensity. Data are presented as the mean \pm standard deviation. ${ }^{\text {\&\&}} \mathrm{P}<0.01$ vs. the control group; ${ }^{* *} \mathrm{P}<0.01$ vs. the TGF- $\beta 1$ group. AKT, protein kinase B; EGCG, epigallocatechin-3-gallate; LY294002, inhibitor of PI3K activity; p-, phosphorylated; PI3K, phosphatidylinositol 3-kinase; PTEN, phosphatase and tensin homolog; TGF- $\beta 1$, transforming growth factor- $\beta 1$.

it has been reported that upregulation of PI3K is likely due to downregulation of PTEN $(20,21)$. The present study also examined the protein expression levels of PTEN in OVA-challenged asthmatic mice with or without EGCG treatment by western blot analysis. The results demonstrated that PTEN was downregulated from $1.00 \pm 0.00$ in the control group to $0.47 \pm 0.11$ in the OVA group $(\mathrm{P}<0.01)$, whereas EGCG recovered the decreased levels of PTEN to similar levels as in the control group (from $0.47 \pm 0.11$ in the OVA group to $0.78 \pm 0.17$ in the OVA + EGCG group; $\mathrm{P}<0.01$ ). Therefore, it may be suggested that EGCG upregulates PTEN expression, and downregulates the expression of $\mathrm{p}-\mathrm{PI} 3 \mathrm{~K}$ and $\mathrm{p}-\mathrm{AKT}$, to modulate the PI3K/AKT signaling pathway in OVA-challenged asthmatic mice.

EGCG suppresses TGF- $\beta 1$-induced EMT in 16HBE cells. To further study the mechanism underlying how EGCG inhibits EMT in asthma, the 16HBE human bronchial epithelial cell line was used in subsequent experiments. It has previously been reported that the PI3K/AKT signaling pathway is involved in EGCG-induced apoptosis of human pancreatic carcinoma cells (22). In the present study, LY294002, which is a selective inhibitor of PI3K, was used as a positive control to explore the potential mechanism underlying the effects of EGCG on EMT in TGF- $\beta 1$-induced 16HBE cells. As expected, RT-qPCR analysis indicated that the mRNA expression levels of E-cadherin were decreased, whereas the mRNA expression levels of $\alpha$-SMA were significantly increased in response to TGF- $\beta 1$, which indicated that TGF- $\beta 1$ may induce EMT in $16 \mathrm{HBE}$ cells. However, EGCG increased the mRNA expression levels of E-cadherin from $0.29 \pm 0.00$ to $0.77 \pm 0.03$, and decreased the levels of $\alpha$-SMA from $4.35 \pm 0.39$ to $2.27 \pm 0.09(\mathrm{P}<0.01)$; EGCG had a similar effect to LY294002 in TGF- $\beta 1$-induced 16HBE cells (Fig. 4A). Similarly, the western blot analysis indicated that the expression levels of E-cadherin were downregulated, whereas the expression levels of $\alpha$-SMA were markedly upregulated by TGF- $\beta 1$ in $16 \mathrm{HBE}$ cells. Conversely, EGCG upregulated the expression of E-cadherin and inhibited the expression of $\alpha$-SMA in TGF- $\beta 1$-induced 16HBE cells, similar to LY294002 (Fig. 4B). Semi-quantitative analysis of E-cadherin and $\alpha$-SMA expression demonstrated that E-cadherin expression was increased from $0.40 \pm 0.06$ to $0.71 \pm 0.07$ in the TGF- $\beta 1+$ EGCG group, whereas $\alpha$-SMA was 
A

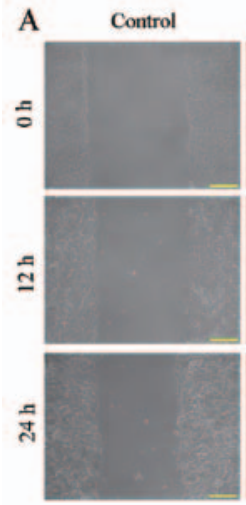

C

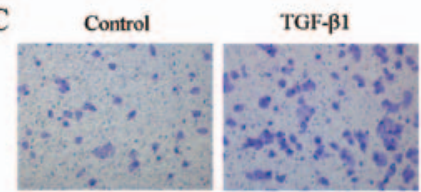

TGF- $\beta 1+$ EGCO

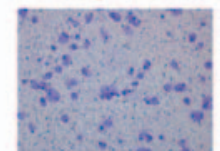

TGF-ק1+EGC
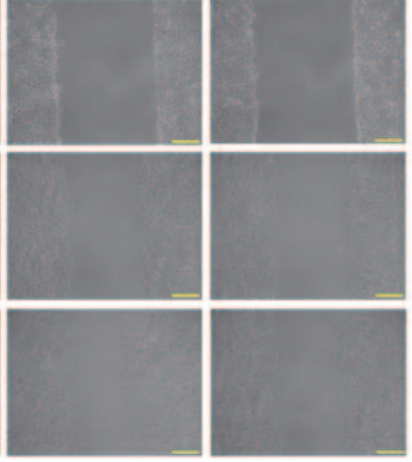

B

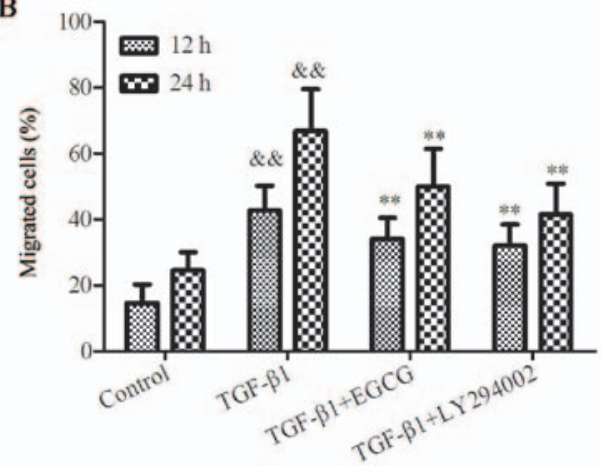

D

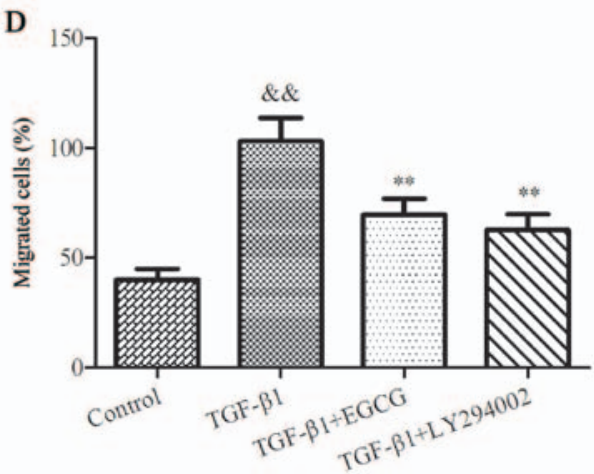

Figure 6. EGCG inhibits the migration of TGF- $\beta 1$-induced 16HBE cells. (A) Wound healing assay was conducted following treatment of TGF- $\beta 1$-induced $16 \mathrm{HBE}$ cells with or without EGCG. Scale bars, $100 \mu \mathrm{M}$. (B) Number of migrated cells was significantly inhibited by EGCG, as determined using a wound healing assay. (C) Transwell assay following treatment of TGF- $\beta 1$-induced 16HBE cells with or without EGCG. Scale bars, $100 \mu$ M. (D) Number of migrated cells was compared between the groups. Data are presented as the mean \pm standard deviation. ${ }^{\& \&} \mathrm{P}<0.01 \mathrm{vs}$. the control group; ${ }^{* *} \mathrm{P}<0.01 \mathrm{vs}$. the TGF- $\beta 1$ group. EGCG, epigallocatechin-3-gallate; LY294002, inhibitor of phosphatidylinositol 3-kinase activity; TGF- $\beta 1$, transforming growth factor- $\beta 1$.

decreased from $2.59 \pm 0.29$ to $1.61 \pm 0.33$ in the TGF- $\beta 1+$ EGCG group $(\mathrm{P}<0.01$, Fig. 4B). Therefore, it may be hypothesized that EGCG inhibits TGF- $\beta 1$-induced EMT in $16 \mathrm{HBE}$ cells, which is likely associated with the PI3K/AKT signaling pathway.

EGCG inhibits the PI3K/AKT signal pathway via upregulation of PTEN expression in TGF- $\beta 1$-induced $16 H B E$ cells. The expression levels of PI3K, p-PI3K, AKT and p-AKT were detected in TGF- $\beta 1$-induced $16 \mathrm{HBE}$ cells with or without EGCG treatment by western blot analysis. The results indicated that the expression levels of PI3K and AKT were not altered by TGF- $\beta 1$ compared with in the control group, whereas the expression levels of p-PI3K and p-AKT were upregulated in $16 \mathrm{HBE}$ cells treated with TGF- $\beta 1$. However, the expression levels of these proteins were significantly downregulated by EGCG treatment. In addition, in the TGF- $\beta 1$ + LY294002 group, the expression levels of p-PI3K and p-AKT were inhibited (Fig. 5A). p-PI3K expression was decreased from $2.72 \pm 0.35$ in the TGF- $\beta 1$ group to $1.98 \pm 0.18$ in the TGF- $\beta 1+$ EGCG group, and p-AKT expression was decreased from $2.34 \pm 0.36$ in the TGF- $\beta 1$ group to $1.71 \pm 0.25$ in the TGF- $\beta 1+$ EGCG group $(\mathrm{P}<0.01)$. The PI3K/AKT pathway may be regulated via PTEN; therefore, the present study explored whether EGCG regulates PTEN expression at the mRNA and protein levels (Fig. 5B and C). The results demonstrated that the mRNA and protein expression levels of PTEN were decreased by TGF- $\beta 1$, whereas EGCG increased the expression levels to a large extent. PTEN mRNA expres- sion was increased from $0.12 \pm 0.01$ in the TGF- $\beta 1$ group to $0.43 \pm 0.00$ in the TGF- $\beta 1+$ EGCG group (Fig. $5 \mathrm{~B}, \mathrm{P}<0.01$ ), and PTEN protein expression was increased from $0.41 \pm 0.04$ in the TGF- $\beta 1$ group to $0.57 \pm 0.07$ in the TGF- $\beta 1+$ EGCG group (Fig. $5 \mathrm{C}, \mathrm{P}<0.01$ ). These results clearly indicated that EGCG may inhibit EMT in asthma via the PTEN/PI3K/AKT signaling pathway.

EGCG inhibits the migration of TGF- $\beta 1$-induced $16 H B E$ cells. During asthma, EMT is reported not only to initiate phenotypic alterations in airway epithelial cells, but also to facilitate migration and invasion of these cells into subepithelial regions of the airway wall, where they contribute to fibrosis (23). It has also been demonstrated that TGF- $\beta 1$-induced EMT results in enhancement of cell migration through the PI3K/AKT pathway (24). In the present study, the effects of EGCG on TGF- $\beta 1$-induced migration of $16 \mathrm{HBE}$ cells were investigated using wound healing and Transwell assays (Fig. 6). The results demonstrated that TGF- $\beta 1$ markedly increased migration of $16 \mathrm{HBE}$ cells, particularly after $24 \mathrm{~h}$. However, cells treated with EGCG exhibited decreased migratory ability after 12 and $24 \mathrm{~h}$ (Fig. 6A). The distance of migration was markedly decreased in the TGF- $\beta 1+$ EGCG group, and was similar to that in the TGF- $\beta 1+$ LY294002 group. The migration rates in the TGF- $\beta 1$, TGF- $\beta 1+$ EGCG and TGF- $\beta 1+$ LY294002 groups were $42.75 \pm 4.34,34.02 \pm 3.73$ and $32.15 \pm 3.64 \%$ after $12 \mathrm{~h}$, and $66.87 \pm 7.33,49.97 \pm 6.62$ and $41.64 \pm 5.34 \%$ after $24 \mathrm{~h}$, respectively $(\mathrm{P}<0.01$, Fig. $6 \mathrm{~B})$. 
A Transwell assay was also conducted to investigate EGCG-induced suppression of migration. Compared with in the control group, TGF- $\beta 1$ increased the migratory ability of 16HBE cells, whereas EGCG suppressed the increased migration (Fig. 6C). Furthermore, the results indicated that the number of cells adherent to the lower membranes of the Transwell chamber were markedly increased from $40.00 \pm 4.09 \%$ in the control group to $103.00 \pm 10.65 \%$ in the TGF- $\beta 1$ group $(\mathrm{P}<0.01)$. However, EGCG decreased the numbers of cell from $103.00 \pm 10.65$ to $69.60 \pm 7.30 \%$; the number of migratory cells was almost two times lower in the TGF- $\beta 1+$ EGCG group than in the TGF- $\beta 1$ group $(\mathrm{P}<0.01)$. A similar effect was detected in the TGF- $\beta 1+$ LY294002 group $(62.80 \pm 7.12 \%)$ (Fig. 6D). These results suggested that EGCG may suppress TGF- $\beta 1$-induced migration of $16 \mathrm{HBE}$ cells.

\section{Discussion}

Structural alterations in the airway epithelium result in abnormal lung function, and airway hyperresponsiveness and remodeling, which involves differentiation of airway epithelial cells into myofibroblasts via EMT, which consequently intensifies the degree of subepithelial fibrosis. Physical alterations in the asthmatic epithelium include a decrease in E-cadherin (25) and an increase in the mesenchymal marker $\alpha$-SMA (12). Damage to the airway epithelium from allergens or other environmental factors can lead to the release of inflammatory factors, which promote epithelial cell migration to allow for wound repair (26). Furthermore, although EMT is a normal biological process that occurs during wound healing, this process becomes detrimental to the airway allowing transient properties to become permanent during allergic responses, including asthma. EGCG has been reported to attenuate TGF- $\beta 1$-induced EMT in renal tubular epithelial cells $(12,27)$. Kim et al reported that EGCG may be useful as an adjuvant therapy for bronchial asthma (28). However, the cellular and molecular mechanisms underlying the effects of EGCG on the pathogenesis and/or treatment of asthma remain to be fully understood. The present study demonstrated that EGCG improves lung function through inhibiting inflammation and EMT induced by an OVA challenge, and suppressing activation of the PI3K/AKT signal pathway via upregulation of PTEN in OVA-challenged asthmatic mice in vivo. In vitro studies confirmed the inhibitory effects of EGCG on TGF- $\beta 1$-induced EMT in 16HBE human bronchial epithelial cells. Furthermore, the results revealed that EGCG inhibited TGF- $\beta 1$-induced migration through suppression of the PI3K/AKT signal pathway via increasing the expression of PTEN in 16HBE cells. These observations provide a novel insight into understanding the protective effects of EGCG on airway remodeling in asthma, and reveal the potential mechanisms underlying the effects of EGCG on bronchial asthma in vivo and in vitro.

Allergen challenges are known to cause persistent inflammation in the airway, which leads to tissue damage. To handle this oxidative insult, the lungs possess inherent mechanisms to repair tissue damage. However, incessant and excessive oxidative insult leads to the release of excessive amounts of inflammatory mediators, including cytokines, interleukins and growth factors, causing chronic inflammation (29). Persistent inflammation in airway tissues may result in structural altera- tions, including airway remodeling and obstruction, which are not fully reversible and result in the progressive loss of lung function. It is generally accepted that airway remodeling involves thickening of the basement membrane, goblet cell metaplasia, deposition of extracellular matrix proteins and mucus hypersecretion, thus resulting in reversible airflow limitations, airway hyperresponsiveness and a decline in lung function $(30,31)$. In the present study, OVA-sensitized mice were examined and the effects of EGCG on the parameters of airway remodeling were analyzed. The results demonstrated that besides increased infiltration of inflammatory cells into the lungs and their accumulation in the BALF, an increased production of IL- 4 , IL-5 and TGF- $\beta 1$ was detected in the lungs and BALF, which corresponded to increased inflammation in response to OVA (Fig. 1). In addition, the results revealed that EGCG significantly inhibited accumulation of inflammatory cells, and prevented infiltration of eosinophils and other inflammatory cells into lung tissues and BALF in OVA-sensitized mice (Fig. 1). It has previously been reported that EGCG protects against toluene diisocyanate-induced airway inflammation in a murine model of asthma (28). Choi et al also demonstrated that EGCG reduces mucin expression in asthmatic mice and nasal epithelial cells from patients with allergic inflammation (32). Therefore, the present in vivo results suggested that administration of EGCG to OVA-sensitized mice may inhibit airway inflammation in chronic asthmatic lungs. However, the molecular mechanisms underlying how EGCG prevents these events require further clarification.

Chronic inflammation of the airways usually results in airway remodeling, which is frequently associated with severe chronic asthma, which poorly responds to conventional anti-inflammatory therapies (33). EMT of airway epithelial cells has been reported to be an important inducer of airway remodeling, since it increases the number of mesenchymal cells migrating to the subepithelial connective tissues where they enhance the production of extracellular matrix proteins leading to bronchial wall fibrosis (34). In addition, it has previously been demonstrated that inflammatory cells are able to promote EMT. Lange-Sperandio et al reported that monocytes or macrophages induce EMT of renal epithelial cells during unilateral ureteral obstruction (35). Minshall et al also demonstrated that eosinophils are involved in EMT of esophageal mucosal epithelial cells (36). In the present study, inflammatory cells, including macrophages, eosinophils and neutrophils, were increased in response to an OVA challenge, both in the lung tissue and BALF of asthmatic mice, whereas EGCG significantly decreased infiltration of these cells (Fig. 1A). Furthermore, $\alpha$-SMA expression is a marker of myofibroblasts, a cell type that suggests an advanced phase of EMT (37). Conversely, E-cadherin is an epithelial cell transmembrane protein in the extracellular domain, which serves an essential role in maintaining the structural integrity of bronchial epithelia and in epithelial polarization; it has previously been demonstrated that a decrease in E-cadherin expression alone could induce EMT in carcinoma cells (38). In OVA-sensitized asthmatic mice, the downregulation of E-cadherin was reversed, whereas the upregulation of $\alpha$-SMA expression was decreased, by EGCG treatment (Fig. 2), thus suggesting that EGCG exerts inhibitory effects on OVA-challenged EMT in vivo. 
EGCG also inhibited the increase of cytokines, including TGF- $\beta 1$, which is a major inducer of EMT and therefore is considered the most active player in the process of airway remodeling (33). TGF- $\beta 1$ is a potent contributor to extracellular matrix formation and has been known as the key mediator of subepithelial fibrosis in asthma (39). In epithelial cells, TGF- $\beta 1$ induces biochemical and morphological alterations toward the mesenchymal phenotype. Therefore, TGF- $\beta 1$-induced $16 \mathrm{HBE}$ human bronchial epithelial cells were used to analyze the effects of EGCG on EMT in vitro. As expected, TGF- $\beta 1$ decreased the protein and mRNA expression levels of E-cadherin and induced the upregulation of $\alpha$-SMA in 16HBE cells, as determined by RT-qPCR and western blot analysis. Conversely, EGCG increased the expression of E-cadherin and inhibited the upregulation of $\alpha$-SMA in TGF- $\beta 1$ induced-16HBE cells (Fig. 4). Therefore, it may be concluded that EGCG inhibits EMT in vivo and in vitro.

It has previously been demonstrated that the PI3K/AKT signal pathway is required for early alterations during EMT $(40,41)$. Various studies have reported that EGCG acts via the PI3K/AKT signaling to exert antioxidant, anti-atherosclerotic and antitumor activities (42-44). In addition, EGCG has been identified as a PI3K inhibitor using a scintillation proximity assay (13). The present in vivo study demonstrated that EMT was inhibited in OVA-challenged asthmatic mice by EGCG through suppression of PI3K/AKT pathway activation (Fig. 3). A previous study revealed that TGF- $\beta 1$ may induce a reversible mesenchymal transition in mammary epithelial NMuMG cells via the PI3K/AKT pathway (45). The PI3K/AKT signal pathway is one of the most commonly activated signal pathways in numerous types of human cancer (46). In the present study, TGF- $\beta 1$-induced activation of PI3K and AKT, and downregulation of PTEN, were significantly reversed by EGCG treatment in vitro (Fig. 5). In addition, PTEN has been reported to inhibit cell migration and proliferation, and promote cell apoptosis via its lipid phosphatase activity, which uses PI3K as a physiological substrate (47). PTEN can also block activation of PI3K by dephosphorylating the signaling lipid phosphatidylinositol-3,4,5-triphosphate (48). Therefore, it may be hypothesized that EGCG inhibits EMT through the PI3K/AKT pathway via upregulating the expression of PTEN in vivo and in vitro.

Activation of EMT signaling usually causes epithelial cells to differentiate into myofibroblasts, enabling migration and invasion within the epithelial layer, thereby initiating subepithelial fibrosis in airway remodeling. Furthermore, PI3K has been implicated in the regulation of cell migration of human neutrophils (49). The present results suggested that TGF- $\beta 1$ enhanced the basal migration of 16HBE cells, whereas blockade of PI3K with LY294002 reduced basal and TGF- $\beta 1$-stimulated cell migration (Fig. 6). Furthermore, EGCG exhibited a similar inhibitory effect as LY294002 with regards to TGF- $\beta 1$-stimulated migration of $16 \mathrm{HBE}$ cells. These data are in agreement with a previous study, which reported that EGCG may serve a critical role in cell motility and migration (50). Therefore, the present study indicated that EGCG may inhibit migration induced by TGF- $\beta 1$ via the PI3K/AKT signal pathway in $16 \mathrm{HBE}$ cells.

In conclusion, the present study demonstrated that EGCG inhibits inflammation and EMT through the PI3K/AKT signaling pathway via upregulating the expression of PTEN in asthma in vivo and in vitro. In addition, EGCG may exert antimigratory effects on TGF- $\beta 1$-induced $16 \mathrm{HBE}$ cells, thus suggesting it may be able to reduce airway remodeling in the epithelium. The present study provides a novel insight supporting a role for EGCG in the prevention of airway inflammation and remodeling in asthma, and proposes that EGCG may be useful as an adjuvant therapy for bronchial asthma.

\section{References}

1. Busse WW and Lemanske RF Jr: Asthma. N Engl J Med 344: 350-362, 2001.

2. Global Asthma Network: The global asthma report 2014. http:// www.globalasthmareport.org/resources/Global_Asthma_Report_ 2014.pdf. Accessed Dec 22, 2016.

3. Lemanske RF Jr and Busse WW: 6. Asthma. J Allergy Clin Immunol 111 (Suppl 2): S502-S519, 2003.

4. Fischer KD, Hall SC and Agrawal DK: Vitamin D supplementation reduces induction of epithelial-mesenchymal transition in allergen sensitized and challenged mice. PLoS One 11: e0149180, 2016.

5. Thiery JP, Acloque H, Huang RY and Nieto MA: Epithelial-mesenchymal transitions in development and disease. Cell 139: 871-890, 2009.

6. Kalluri R and Weinberg RA: The basics of epithelial-mesenchymal transition. J Clin Invest 119: 1420-1428, 2009.

7. Massagué J: TGFbeta in cancer. Cell 134: 215-230, 2008.

8. Willis BC and Borok Z: TGF-beta-induced EMT: mechanisms and implications for fibrotic lung disease. Am J Physiol Lung Cell Mol Physiol 293: L525-L534, 2007.

9. Kelly MM, O'Connor TM, Leigh R, Otis J, Gwozd C, Gauvreau GM, Gauldie J and O'Byrne PM: Effects of budesonide and formoterol on allergen-induced airway responses, inflammation, and airway remodeling in asthma. J Allergy Clin Immunol 125: 349-356, 2010.

10. Khan N and Mukhtar H: Multitargeted therapy of cancer by green tea polyphenols. Cancer Lett 269: 269-280, 2008.

11. Suganuma M, Okabe S, Sueoka N, Sueoka E, Matsuyama S, Imai K, Nakachi K and Fujiki H: Green tea and cancer chemoprevention. Mutat Res 428: 339-344, 1999.

12. Wang Y, Liu N, Su X, Zhou G, Sun G, Du F, Bian X and Wang B: Epigallocatechin-3-gallate attenuates transforming growth factor-betal induced epithelial-mesenchymal transition via Nrf2 regulation in renal tubular epithelial cells. Biomed Pharmacother 70: 260-267, 2015.

13. Van Aller GS, Carson JD, Tang W, Peng H, Zhao L, Copeland RA, Tummino PJ and Luo L: Epigallocatechin gallate (EGCG), a major component of green tea, is a dual phosphoinositide-3-kinase/mTOR inhibitor. Biochem Biophys Res Commun 406: 194-199, 2011.

14. Wu SY, Silverberg JI, Joks R, Durkin HG and Smith-Norowitz TA: Green tea (Camelia sinensis) mediated suppression of IgE production by peripheral blood mononuclear cells of allergic asthmatic humans. Scand J Immunol 76: 306-310, 2012.

15. Bani D, Giannini L, Ciampa A, Masini E, Suzuki Y, Menegazzi M, Nistri S and Suzuki H: Epigallocatechin-3-gallate reduces allergen-induced asthma-like reaction in sensitized guinea pigs. J Pharmacol Exp Ther 317: 1002-1011, 2006.

16. Kimata H: Effect of viewing a humorous vs. nonhumorous film on bronchial responsiveness in patients with bronchial asthma. Physiol Behav 81: 681-684, 2004.

17. Shi J, Liu F, Zhang W, Liu X, Lin B and Tang X: Epigallocatechin-3-gallate inhibits nicotine-induced migration and invasion by the suppression of angiogenesis and epithelial-mesenchymal transition in non-small cell lung cancer cells. Oncol Rep 33: 2972-2980, 2015.

18. Chen S, Xu Y, Chen Y, Li X, Mou W, Wang L, Liu Y, Reisfeld RA, Xiang R, Lv D and Li N: SOX2 gene regulates the transcriptional network of oncogenes and affects tumorigenesis of human lung cancer cells. PLoS One 7: e36326, 2012

19. Yadav UC, Naura AS, Aguilera-Aguirre L, Ramana KV, Boldogh I, Sur S, Boulares HA and Srivastava SK: Aldose reductase inhibition suppresses the expression of Th2 cytokines and airway inflammation in ovalbumin-induced asthma in mice. J Immunol 183: 4723-4732, 2009.

20. Wang H, Quah SY, Dong JM, Manser E, Tang JP and Zeng Q: PRL-3 down-regulates PTEN expression and signals through PI3K to promote epithelial-mesenchymal transition. Cancer Res 67: 2922-2926, 2007. 
21. Kim SR, Lee KS, Park SJ, Min KH, Lee KY, Choe YH, Lee YR, Kim JS, Hong SJ and Lee YC: PTEN down-regulates IL-17 expression in a murine model of toluene diisocyanate-induced airway disease. J Immunol 179: 6820-6829, 2007.

22. Liu S, Wang XJ, Liu Y and Cui YF: PI3K/AKT/mTOR signaling is involved in (-)-epigallocatechin-3-gallate-induced apoptosis of human pancreatic carcinoma cells. Am J Chin Med 41: 629-642, 2013

23. Johnson JR, Roos A, Berg T, Nord M and Fuxe J: Chronic respiratory aeroallergen exposure in mice induces epithelial-mesenchymal transition in the large airways. PLoS One 6: e16175, 2011.

24. Bakin AV, Tomlinson AK, Bhowmick NA, Moses HL and Arteaga CL: Phosphatidylinositol 3-kinase function is required for transforming growth factor beta-mediated epithelial to mesenchymal transition and cell migration. J Biol Chem 275 : 36803-36810, 2000.

25. Hackett TL, de Bruin HG, Shaheen F, van den Berge M, van Oosterhout AJ, Postma DS and Heijink IH: Caveolin-1 controls airway epithelial barrier function. Implications for asthma. Am J Respir Cell Mol Biol 49: 662-671, 2013.

26. Fischer KD and Agrawal DK: Vitamin D regulating TGF- $\beta$ induced epithelial-mesenchymal transition. Respir Res 15: 146, 2014.

27. Chang JZ, Yang WH, Deng YT, Chen HM and Kuo MY: EGCG blocks TGF $\beta 1$-induced CCN2 by suppressing JNK and p38 in buccal fibroblasts. Clin Oral Investig 17: 455-461, 2013.

28. Kim SH, Park HJ, Lee CM, Choi IW, Moon DO, Roh HJ, Lee HK and Park YM: Epigallocatechin-3-gallate protects toluene diisocyanate-induced airway inflammation in a murine model of asthma. FEBS Lett 580: 1883-1890, 2006.

29. Pascual RM and Peters SP: Airway remodeling contributes to the progressive loss of lung function in asthma: an overview. J Allergy Clin Immunol 116: 477-487, 2005.

30. Tagaya $\mathrm{E}$ and Tamaoki J: Mechanisms of airway remodeling in asthma. Allergol Int 56: 331-340, 2007.

31. Sumi Y and Hamid Q: Airway remodeling in asthma. Allergol Int 56: 341-348, 2007.

32. Choi YS, Bae CH, Song SY and Kim YD: The effect of epigallocatechin-3-gallate in allergic airway inflammation. Rhinology 52: 406-412, 2014.

33. Cho JY: Recent advances in mechanisms and treatments of airway remodeling in asthma: a message from the bench side to the clinic. Korean J Intern Med 26: 367-383, 2011.

34. Royce SG, Cheng V, Samuel CS and Tang ML: The regulation of fibrosis in airway remodeling in asthma. Mol Cell Endocrinol 351: $167-175,2012$.

35. Lange-Sperandio B, Trautmann A,Eickelberg O, Jayachandran A, Oberle S, Schmidutz F, Rodenbeck B, Hömme M, Horuk R and Schaefer F: Leukocytes induce epithelial to mesenchymal transition after unilateral ureteral obstruction in neonatal mice. Am J Pathol 171: 861-871, 2007.

36. Minshall EM, Leung DY, Martin RJ, Song YL, Cameron L, Ernst P and Hamid Q: Eosinophil-associated TGF-beta1 mRNA expression and airways fibrosis in bronchial asthma. Am J Respir Cell Mol Biol 17: 326-333, 1997.

37. Boukhalfa G, Desmoulière A, Rondeau E, Gabbiani G and Sraer JD: Relationship between alpha-smooth muscle actin expression and fibrotic changes in human kidney. Exp Nephrol 4: 241-247, 1996
38. Cano A, Pérez-Moreno MA, Rodrigo I, Locascio A, Blanco MJ, del Barrio MG, Portillo F and Nieto MA: The transcription factor snail controls epithelial-mesenchymal transitions by repressing E-cadherin expression. Nat Cell Biol 2: 76-83, 2000.

39. Makinde T, Murphy RF and Agrawal DK: The regulatory role of TGF-beta in airway remodeling in asthma. Immunol Cell Biol 85: 348-356, 2007.

40. Higaki M and Shimokado K: Phosphatidylinositol 3-kinase is required for growth factor-induced amino acid uptake by vascular smooth muscle cells. Arterioscler Thromb Vasc Biol 19: 2127-2132, 1999 .

41. Krymskaya VP, Hoffman R, Eszterhas A, Ciocca V and Panettieri RA Jr: TGF-beta 1 modulates EGF-stimulated phosphatidylinositol 3-kinase activity in human airway smooth muscle cells. Am J Physiol 273: L1220-L1227, 1997.

42. Zhang Y, He Q, Dong J, Jia Z, Hao F and Shan C: Effects of epigallocatechin-3-gallate on proliferation and differentiation of mouse cochlear neural stem cells: involvement of PI3K/Akt signaling pathway. Eur J Pharm Sci 88: 267-273, 2016.

43. Xuan F and Jian J: Epigallocatechin gallate exerts protective effects against myocardial ischemia/reperfusion injury through the PI3K/Akt pathway-mediated inhibition of apoptosis and the restoration of the autophagic flux. Int J Mol Med 38: 328-336, 2016.

44. Liu S, Xu ZL, Sun L, Liu Y, Li CC, Li HM, Zhang W, Li CJ and Qin W: (-)-Epigallocatechin-3-gallate induces apoptosis in human pancreatic cancer cells via PTEN. Mol Med Rep 14: 599-605, 2016

45. Piek E, Moustakas A, Kurisaki A, Heldin CH and ten Dijke P: TGF-(beta) type I receptor/ALK-5 and Smad proteins mediate epithelial to mesenchymal transdifferentiation in NMuMG breast epithelial cells. J Cell Sci 112: 4557-4568, 1999.

46. Yap TA, Garrett MD, Walton MI, Raynaud F, de Bono JS and Workman P: Targeting the PI3K-AKT-mTOR pathway: progress, pitfalls, and promises. Curr Opin Pharmacol 8: 393-412, 2008.

47. Tamura M, Gu J, Matsumoto K, Aota S, Parsons R and Yamada KM: Inhibition of cell migration, spreading, and focal adhesions by tumor suppressor PTEN. Science 280: 1614-1617, 1998.

48. Kwak YG, Song CH, Yi HK, Hwang PH, Kim JS, Lee KS and Lee YC: Involvement of PTEN in airway hyperresponsiveness and inflammation in bronchial asthma. J Clin Invest 111: 1083-1092, 2003

49. Hirsch E, Katanaev VL, Garlanda C, Azzolino O, Pirola L, Silengo L, Sozzani S, Mantovani A, Altruda F and Wymann MP: Central role for $\mathrm{G}$ protein-coupled phosphoinositide 3-kinase gamma in inflammation. Science 287: 1049-1053, 2000.

50. Barenys M, Gassmann K, Baksmeier C, Heinz S, Reverte I, Schmuck M, Temme T, Bendt F, Zschauer TC, Rockel TD, et al: Epigallocatechin gallate (EGCG) inhibits adhesion and migration of neural progenitor cells in vitro. Arch Toxicol 91: 827-837, 2017.

This work is licensed under a Creative Commons Attribution-NonCommercial-NoDerivatives 4.0 International (CC BY-NC-ND 4.0) License. 